\title{
Multi-Objective Thermal Desing Optimization of a Shell and Tube Condenser through Global Best Algorithm
}

\author{
Oğuz Emrah TURGUT \\ Ege University, Engineering Faculty, Mechanical Engineering Department, 35040, \\ IZMIR
}

(Alınıs / Received: 23.11.2016, Kabul / Accepted: 23.03.2017, Online Yayınlanma / Published Online: 02.05.2017)

Keywords Global Best Algorithm, Multi objective optimization, Shell and tube heat exchanger, Thermal design

\begin{abstract}
This study considers Global Best Algorithm (GBEST) for thermoeconomic design of a shell and tube condenser. Design process sustained by the traditional procedures involves tedious and exhaustive iterative calculations which sometimes becomes time consuming and may not lead to economically optimum configuration. Literature studies have shown that solution strategy offered by stochastic optimization methods such as Global Best Algorithm over thermal design of any kind of heat exchanger is promising solution strategy according to the optimum results found in each study. Firstly, optimization performance of the GBEST is assessed with ten benchmark problems and numerical outcomes are compared with those obtained from different literature optimization methods. A case study taken from literature has been solved by GBEST along with famous optimizers of Particle Swarm Optimization and Differential Evolution in the framework of single and multi objective optimization so as to optimize the problem objectives of total cost of heat exchanger and average overall heat transfer coefficient. GBEST not only finds more favourable results than those obtained from the compared optimization algorithms, but also improves the preliminary design taken from literature study. Pareto curve is constructed for multi objective optimization and best solution on the curve is selected by three renowned decision making methods of LINMAP, TOPSIS, and Shannon's entropy theory. Finally, a sensitivity analysis has been performed in order to observe the variational influences of design parameters over optimization objectives.
\end{abstract}

\section{Gövde Boru Tipli Kondenserlerin Global Eniyi Arama} Algoritmasıyla Çok Amaçlı Termal Tasarım Optimizasyonu

\begin{tabular}{|c|c|}
\hline Anahtar Kelimeler & Özet: Bu çalışmada Global Eniyi Arama algoritması gövde borulu \\
\hline $\begin{array}{l}\text { Global Eniyi } \\
\text { Arama }\end{array}$ & düzenli bir kondenserin termal tasarımını oluşturmak için \\
\hline $\begin{array}{l}\text { Arama } \\
\text { algoritması, Çok }\end{array}$ & Konvensiyonel \\
\hline
\end{tabular}
algoritması, Çok 
O.E. Turgut, Multi-Objective Thermal Design of a Shell and Tube Condenser through Global Best Algorithm

amaçlı

optimizasyon,

Gövde borulu isı

değiștirgeci,

Termal tasarım tarafından sağlanan tasarım süreci, zaman alıcı olmasının yanısıra ekonomik açıdan da beklenen sonuçları sağlayamayabilmektedir. Literatür çalışmaları Global Eniyi Arama algoritması gibi stokastik optimizasyon algoritmalarını herhangi bir 1 sı değiştiricinin termal tasarımında uygulanmasının literatürde yapılan diğer çalışmalardan elde edilen sonuçlara dayanarak oldukça olumlu çıktılar verdiğini göstermektedir. Bu çalışmada ilk olarak, Global Eniyi Arama algoritmasının optimizasyon performansı 10 adet optimizasyon test fonksiyonu kullanılarak değerlendirilmiştir. Literatür çalışmalarından alınan bir örnek optimizasyon problemi Global Eniyi Arama algoritması ile birlikte Diferansiyel Evrim ve Parçacık Sürü Optimizasyon algoritmaları tarafından minimum toplam ısı değiştirici maliyeti ve maksimum toplam ısı transferi katsayısı gibi amaç fonksiyonlarını optimize etmek için tek ve çok amaçlı optimizasyon yöntemleri kullanılarak çözülmüștür. Global Eniyi Arama algoritması diğer karșılaștırılan algoritmalardan daha olumlu sonuçlar elde etmekle kalmamıs ayrıca örnek optimizasyon probleminde tasarlanan değerlerin gelişmesinde önemli bir rol oynamıștır. Çok amaçlı optimizasyon için birbirine üstünlük kuramayan sonuçlardan olușan Pareto eğrisi inşa edilmiş ve eğri üzerindeki en iyi sonuç LINMAP, TOPSIS ve Shannon'un entropi teorisi gibi üç önemli karar verme mekanizması tarafından seçilmiștir. Çalışmanın sonunda ise hassasiyet analizi uygulanarak tasarım parametrelerinin optimizasyon amaç fonskiyonları üzerindeki değişimsel etkileri gözlemlenmiștir.
*Corresponding Author e-mail: oeturgut@hotmail.com

\section{Introduction}

Effective and efficient heat transfer from process fluids is an essential consideration for chemical, nuclear, and industrial applications. Therefore, proper design of a heat exchanger for relevant industries is important for minimizing extravagant expenditures in terms of total cost of a heat exchange process. In order to accomplish this aim , there are plenty type of heat exchangers available in the market. Among these different type of heat exchange configurations, shell and tube heat exchangers are the most widely utilized ones and contribute more than $\% 65$ of the heat exchangers in chemical process industries [1]. Shell and tube heat exchangers can procure relatively large ratios of total heat exchange area to volume which is greater than 700 $\mathrm{m}^{2} / \mathrm{m}^{3}$ for gases and greater than 300 $\mathrm{m}^{2} / \mathrm{m}^{3}$ for liquids and they can be easily cleaned thanks to their intrinsic structural configuration [2]. They can be designed for high pressure requiring applications and utilized in processes where there is a high pressure difference between two or more heat transfer mediums. They can offer high heat transfer efficiencies, reduced overall cost and lower total weight for specific heat duties.

Shell and tube heat exchangers consist of plenty of structural components including tubes, baffles, front and rear heads, tube sheets and nozzles. Favourable combination of these components not only leads to a considerable reduction in total cost but also increase total amount of heat transfer that occurs between two streams. For that reason, a designer 
should give utmost importance to efficient construction of these major elements of heat exchangers whose structural modelling is under the effect of the working conditions such as operation pressures, temperatures, thermal stress, corrosion characteristics of fluids, etc. [1]. Mathematical modelling of a shell and tube heat exchanger requires tedious design process involving exhaustive trial-anderror based solution procedure to satisfy designer's needs, which covers a plausible compromise between predetermined pressure drop rates and imposed heat duties on a heat exchanger[3-5]. However, as it was mentioned before, total calculation process is likely to burden substantial computational cost and may not lead to cost effective design.

Total cost of heat exchanger is an important parameter that should be considered vastly on the course of design process. Considering the widespread utilization of heat exchangers in relevant industries, obtaining minimum cost should be the primary goal for the designers. As the overall cost of heat exchanger depends of total heat transfer area for a given heat duty, estimation of this design parameter should be the uttermost concern for a designer. In addition to this, there are numerous ways to enhance heat transfer between two working fluids, which includes extended fin geometries, coiled tubes, treated and rough surfaces, fluid vibration, and creating longitudional vortices in the flow [6-8]. Taking care of all these parameters paves the way for lesser energy consumption while providing a beneficial design with respect to thermal and economic aspects.

Versatile and efficient heat exchanger design has been an ongoing issue for designers attempting to optimize major components of a heat exchanger in order to attain the minimum total cost of the device. Many different type of objective functions and optimization strategies have been proposed by the reserachers [10]. Considering the objective function to be optimized, most of the studies are concerned with the sum of the capital investment cost which is the strong function of the total heat transfer area and the energy costs that are related to pumping losses $[1,8$ 18]. Another type of objective function to be defined for heat exchanger optimization was minimizing entropy generation while satisfying heat duty and pressure drop constraints [19-22].

Literature comprises variety of optimization methods to be used for determining favourable design of shell and tube heat exchangers. Early works on this problem mainly utilized traditional optimization methods including Lagrange multiplier [23-25] and Linear programming techniques [26 -28]. Most of the gradient descent based optimization methods are prone to be getting trapped in local optimum points on the search space depending on the complexity of the objective function and initial guess. Therefore, utilization of these methods on the heat exchanger design seems irrational for designers as this design problem can be viewed as a large scale, discrete and combinatorial optimization problem relying on its nature [33]. Recently, metaheuristic optimization algorithms have been not only frequently applied in each department of engineering but also have many implementation in the context of heat exchanger design. Genetic algorithms were found to be an effective approach and have pioneered many studies concerning the shell and tube heat exchanger optimization [29 - 30]. Also many evolutionary optimization methods have been utilized to design shell and tube heat exchangers in both 
O.E. Turgut, Multi-Objective Thermal Design of a Shell and Tube Condenser through Global Best Algorithm

aspects of thermal and economic considerations. Cuckoo Search [1], Particle Swarm Optimization $[8,16,18,32]$, Firefly Optimization [9], Imperialist Competitive Algorithm [11], Biogeography-based Optimization [12], Artificial Bee Colony [15], Differential Evolution[31] are the optimizers which were previously applied for thermoeconomic optimization of shell and tube heat exchangers.

Literature survey on this issue reveals that there has been fewer studies related to the optimum design shell and tube condensers both considering thermal and economic aspects. Haseli et al. [34] used Sequential Quadratic Programming (SQP) method to optimize the operating temperatures of shell and tube heat exchangers in terms of maximum exergy with subjected to the condensation of the total mass flow of vapor. The effect of condensation temperatures on the system performance was also detailly discussed in the aformentioned study. Haseli et al. [22] also made a comprehensive investigation on the thermal efficiency of a shell and tube condenser by applying exergy efficiency as an objective function to be evaluated for performance assessment. Mentioned study was accomplished to analyze local exergy as well as overall exergy efficiencies of the overall system. Khalifeh Soltan et al. [35] proposed a computer program based solution procedure to obtain an optimum baffle spacing for shell and tube condenser. Considering the balanced effects of the total cost of heat exchange area and pumping power, a set of correlation is presented as a supply to literature methods. Hajabdollahi et al. [32] made particle swarm and genetic algorithm based optimization of a shell and tube condenser with respect to thermoeconomic point of view. Main objective is to find optimal cost of shell and tube condenser while satisfying imposed problem constraints.

In this study, a thermo - economic design of shell and tube condenser will be investigated through the optimization algorithm which was previously proposed by the author this study called Global Best Algorithm [45]. Global Best Algorithm (GBEST) utilizes the perturbation equations of more than one optimization algorithm simultaneously and probes around the current best solution through this unique mechanism which makes it so effective in finding global optimum solution. Algorithmic structure of GBEST is different from other optimization methods in literature as this method is solely based on exploiting the promising areas in the search space, not similar to the algorithms those are structually based on maintaining a proper balance between exploration and exploitation. Main aim of using GBEST in this kind of optimization problem is to assess its performance on multi-objective optimization problems with having highly non-linear objective function characteristics. This is the first application of multi-objective optimization on thermal design of a shell and tube condenser, therefore its contribution to literature is almost undeniable. Design variables selected to be optimized are iteratively adjusted by the proposed optimization strategy in order to retain optimum objective functions of minimum cost of heat exchanger and overall heat transfer coefficient in both simultaneous and separated manner. Pareto curve is constructed to visualize the condtradictive behaviors of these two conflicting and binding objectives mathematically. Best solution on the frontier is decided by the widely accepted and renowned decision making methods of LINMAP, TOPSIS, and Shannon's entropy theory according 
O.E. Turgut, Multi-Objective Thermal Design of a Shell and Tube Condenser through Global Best Algorithm

to their respective deviation index values. In addition, sensitivity analysis is made in order to observe the variational influences of the considered design parameter over the remaining ones. Next section will explain the thermal modelling of shell and tube condensers.

\section{Thermal Design of a Shell and Tube Condenser}

Thermal analysis has been established on the following assumptions those also have been practical in design purposes.:

- Shell side of the heat exchanger is related with condensing flow while intube flow is concerned with cooling fluid

- No pressure drop is considered in shell side

- Saturated steam is changed into saturated liquid in the condenser. No superheat or subcooled effects are considered.

Based on these premises given above, mathematical modelling formulations will be presented by the below given equations. Total heat transfer between two mediums is calculated by

$Q=U_{\text {aver }} \cdot A_{t o t} \cdot \Delta T_{l m}$

Where the logarithmic mean temperature difference $\left(\Delta \mathrm{T}_{\mathrm{lm}}\right)$ can be equated by the following:

$$
\Delta T_{\text {lm }}=\frac{\left(\Delta T_{\text {in }}-\Delta T_{\text {out }}\right)}{\ln \left(\Delta T_{\text {in }} / \Delta T_{\text {out }}\right)}
$$

Where $\Delta \mathrm{T}_{\text {in }}=\mathrm{T}_{\text {sat }}-\mathrm{T}_{\text {tube,in }}$ and $\Delta \mathrm{T}_{\text {in }}=\mathrm{T}_{\text {sat }}$ $\mathrm{T}_{\text {tube,out. }}$ In Eq (1), $\mathrm{A}_{\text {tot }}$ is the total heat exchange surface; and $U_{\text {aver }}$ is averaged overall heat transfer coefficient between inlet and outlet of the tubes. As there can be a huge variation in heat transfer coefficient rates along the heat exchanger, averaged values of overall heat transfer coefficients are taken into account with the following formulation:

$$
U_{\text {aver }}=\left(U_{\text {in }}+U_{\text {out }}\right) / 2
$$

Where $U_{\text {in }}$ and $U_{\text {out }}$ are respectively overall heat transfer coefficients at inlet and outlet of the tube pack. Calculating heat transfer coefficient in -tube side is rather simple than those at the shell side which requires tedious iterations due to its direct dependence on heat flux. Heat transfer coefficient for in-tube flow is calculated by famous Petukhov Kirilow correlation.

$$
N u=\frac{0.5 f(\mathrm{Re}-1000) \operatorname{Pr}}{1+12.7(f / 2)^{0.5}\left(\operatorname{Pr}^{2 / 3}-1\right)}
$$

if $(2300<\mathrm{Re}<10000)$

$$
N u=\frac{0.5 f(\operatorname{Re}) \operatorname{Pr}}{1.07+12.7(f / 2)^{0.5}\left(\operatorname{Pr}^{2 / 3}-1\right)}
$$

if $(10000<\operatorname{Re}<100000)$

Where $f$ is the friction factor calculated as

$$
f=(1.58(\mathrm{Re})-3.28)^{-2}
$$

Finally, convection heat transfer coefficient for in-tube flow is calculated by virtue of Nusselt number

$h_{\text {intube }}=N u \cdot k_{l} / d_{\text {in }}$

Shell side heat transfer coefficient for condensate flow is obtained by the formulation proposed in Kakaç et al.[2] with the below given formulation

$$
\begin{aligned}
& h_{\text {shell }}=0.728\left(\frac{\rho_{l}^{2} \cdot g \cdot h_{f g} \cdot k_{l}^{3}}{\mu_{l} \cdot \Delta T_{w} \cdot d_{\text {out }}}\right)^{0.25} \\
& \left(\frac{1}{N^{1 / 6}}\right)
\end{aligned}
$$


Where $\mathrm{N}$ is the number of tube in a vertical column and predicted by the set of equations under the influence of tube arrangement

For $45^{\circ}-90^{\circ}$ arrangement

$N=\frac{\sqrt{4 \cdot c l \cdot p_{t}^{2} \cdot N_{T} / \pi}}{d_{\text {out }}+p_{t}}$

For $30^{\circ}-60^{\circ}$ arrangement

$$
N=\frac{\sqrt{\sqrt{4 \cdot c l \cdot p_{t}^{2} \cdot N_{T} / \pi}}}{d_{\text {out }}+\sqrt{3} p_{t}}
$$

Where tube pitch $p_{t}=d_{\text {out }} \times p_{r}$ and $p_{r}$ is pitch ratio ; $\mathrm{cl}$ is tube layout constant which is equal to 1.0 for $45^{\circ}-90^{\circ}$ and is equal to 0.87 for $30^{\circ}-60^{\circ}$ tube arrangements; and $\mathrm{N}_{\mathrm{T}}$ is total number of tubes. In $\mathrm{Eq}(8), \Delta \mathrm{T}_{\mathrm{w}}$ is the temperature difference between saturated flow at shell side and the fouling at tube surface. This parameter can also be formed by

$$
\Delta T_{w}=\Delta T-R_{t} \cdot q^{\prime \prime}
$$

Where $\Delta \mathrm{T}$ is the local temperature difference between streams, $q^{\prime \prime}=U \Delta T$ is the imposed heat flux, and $\mathrm{R}_{\mathrm{t}}$ is the total heat resistance which can be calculated as

$$
\begin{aligned}
& R_{t}=R_{\text {fout }}+\left[\frac{1}{h_{\text {intube }}}+R_{\text {fin }}\right] \frac{d_{\text {out }}}{d_{\text {in }}} \\
& +\frac{t_{\text {wall }}}{k_{\text {wall }}} \cdot \frac{d_{\text {out }}}{D_{m}}
\end{aligned}
$$

Where $R_{\text {fin }}$ and $R_{\text {fout }}$ respectively stand for the fouling resistances for inner and outer surface of the tubes; $d_{\text {in }}$ and $d_{\text {out }}$ represent the inner and outer diameter of the tubes; $t_{w a l l}$ is the thickness of the tube wall; $\mathrm{k}_{\mathrm{wall}}$ is the heat conductivity of the tubes; and $D_{m}$ is the mean diameter approximated as

$$
D_{m}=\frac{d_{\text {out }}-d_{\text {in }}}{\ln \left(\frac{d_{\text {out }}}{d_{\text {in }}}\right)}
$$

Where $d_{\text {in }}=0.8 d_{\text {out. }}$. Consequently, overall heat transfer coefficient becomes

$$
\frac{1}{U}=R_{t}+\frac{1}{h_{\text {shell }}}
$$

Therefore, Eq.(11) is taken its final form such that

$$
\Delta T_{w}=\Delta T\left(1-R_{t} \cdot U\right)
$$

In order to retain overall heat transfer coefficient for both inlet and outlet of tube banks, iterative procedure described in algorithm is proposed [2].

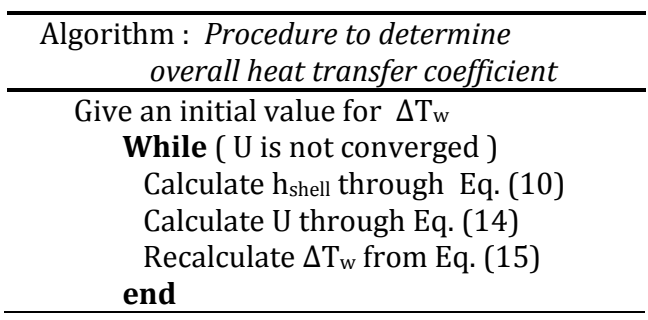

This procedure repeats itself until $U$ value is converged. After determination of average overall heat transfer coefficient for inlet and outlet of the tube bank, calculation of total heat transfer area $\left(A_{\text {tot }}\right)$ is come into practice

$$
A_{\text {tot }}=Q^{\prime}\left(U_{\text {aver }} \cdot \Delta T_{\text {lm }}\right)
$$

And, the corresponfing tube length is calculated by

$$
L=\frac{A_{\text {tot }}}{N_{T} \cdot \pi \cdot d_{\text {out }}}
$$


A decisive parameter for heat exchanger is shell diameter $\left(D_{s}\right)$ which is dependent of tube layout constant (cl), pitch ratio $\left(\mathrm{p}_{\mathrm{r}}\right)$, total heat transfer area $\left(A_{\text {tot }}\right)$, tube outer diameter $\left(\mathrm{d}_{\text {out }}\right)$, and heat exchanger length (L) can be formulated by the following equation

$$
D_{s}=0.637 \sqrt{\frac{c l}{c p t}}\left(\frac{A_{\text {tot }} \cdot p_{r}^{2} \cdot d_{\text {out }}}{L}\right)^{0.5}
$$

Where cpt stands for the incomplete coverage of shell diameter by the tubes and is equal to 0.93 for one tube pass. Total pressure drop at the tube side is the summation of frictional and return losses and can be described in the equation form of:

$$
\Delta p_{t o t}=\Delta p_{f}+\Delta p_{r}
$$

Where $\Delta \mathrm{p}_{\mathrm{f}}$ is the frictional pressure drop occured in the tube expressed with the following form

$$
\Delta p_{f}=4 \cdot f_{t} \frac{L \cdot N_{p}}{d_{i n}} \frac{G^{2}}{2 \cdot \rho_{l}}
$$

Where $\mathrm{N}_{\mathrm{p}}$ represents the number of tube pass in the exchanger and $f_{t}$ is the friction factor for pressure drop calculation and formulated by

$$
f_{t}=0.046 \cdot \mathrm{Re}^{-0.2}
$$

The pressure crop caused by the return bends is calculated by

$$
\Delta p_{r}=4 \cdot N_{p} \cdot \frac{\rho v^{2}}{2}
$$

Total cost of heat exchanger is considered as one of the objectives that should be optimized in an efficient way. Therefore, its respective mathematical expression should be briefly defined. Total cost is comprised of the expenditures caused by the cost of heat transfer area along with the operational cost for the pumping power.

$C_{\text {total }}=C_{\text {inv }}+C_{\text {oper }}$

Calculation of investment cost is strongly related with total heat exchange area and can be mathematically expressed by [36]

$$
C_{i n v}=8500+409 A_{t o t}^{0.85}
$$

Operational cost brought about by the pumping power to conquer the frictional losses in the tubes are computed from the following expression

$$
\begin{gathered}
C_{\text {oper }}=\sum_{j=1}^{n y} \frac{C_{o}}{(1+i)^{j}} \\
C_{o p}=P P \cdot c_{e l} \cdot \tau \\
P P=\frac{1}{\eta_{p}}\left(\frac{\dot{m}_{c}}{\rho_{l}} \Delta P_{t o t}\right)
\end{gathered}
$$

Where ny is the life time of the heat exchanger; $i$ is the annual discount rate; $c_{e l}$ is the price of electricity; $\eta_{p}$ is the pump efficiency; and $\tau$ is the active operational hours per year. In addition, there has also been imposed design constraints suct that shell diameter should be less than $5.5 \mathrm{~m}$. while total length of the tubes should be shorter than $12.0 \mathrm{~m}$. Therefore, when definining objective function, these design constraints are taken into account with such given formulations 
O.E. Turgut, Multi-Objective Thermal Design of a Shell and Tube Condenser through Global Best Algorithm

$\arg \min f_{i}(\vec{x})+\sum_{k=1}^{m} P\left[g_{k}(\vec{x})\right]^{2}$

with subject to:

$f_{i}(\vec{x}) \in\left[f_{1}(\vec{x}), f_{2}(\vec{x}), \ldots, f_{n}(\vec{x})\right]$,

$i=1,2, \ldots, n$

$g_{k}(\vec{x}) \leq 0, \quad k=1,2, \ldots, m$

$x_{\min } \leq x_{j} \leq x_{\max }, \quad j=1,2, \ldots, D$

Where $f_{i}(\mathrm{x})$ is $\mathrm{n}$ number of objectives to be optimized, $g_{k}(\mathrm{x})$ is the $\mathrm{m}$ number of problem constraints, $\vec{x}$ is Ddimensional decision variable set, and $\mathrm{P}$ is the static penalty factor which eliminates unfeasible solutions in the search space.

\section{Numerical Benchmark on Global Best Algorithm}

This section deals with the numerical assessment of the proposed Global Best Algorithm by virtue of 10 widely known optimization test functions whose formulations are given in Table 2 . Numerical outcomes those given in Table 1 are compared with those obtained from the highly reputed optimization algorithms of Backtracking Search Algorithm(BSA) [37], Intelligent tuned Harmony Search (ITHS) [38], Bat
Algorithm (BAT) [39], Quantum behaved Particle Swarm Optimization (QPSO) [40], Big Bang - Big Crunch (BB-BC) [41], and Differential Search (DS) [42] in order to assess the predicitive performance of the GBEST in terms of statistical analysis. Total number of 100000 function evaluations along with 50 consecutive algorithm runs have been performed for each 30 Dimensional benchmark problem in Table 1 due to their unique stochastic nature. Numerical results obtained from statistical comparison reveal that GBEST gets the minimum results for each optimization case and hereby outperforms the compared optimization algorithms with respect to solution accuracy and efficiency. 
O.E. Turgut, Multi-Objective Thermal Design of a Shell and Tube Condenser through Global Best Algorithm

Table 1. Statistical results of compared optimization algorithms

\begin{tabular}{|c|c|c|c|c|}
\hline & Best & Mean & Std.dev. & Worst \\
\hline \multicolumn{5}{|l|}{$f_{1}$ Levy } \\
\hline GBEST & 4.34E-09 & 5.87E-09 & $1.91 \mathrm{E}-09$ & 8.12E-09 \\
\hline BSA & 5.02E-09 & $2.11 \mathrm{E}-08$ & $1.12 \mathrm{E}-08$ & $6.38 \mathrm{E}-08$ \\
\hline ITHS & $8.47 \mathrm{E}-05$ & $2.61 \mathrm{E}-02$ & $2.98 \mathrm{E}-02$ & $9.15 \mathrm{E}-02$ \\
\hline BAT & $2.11 \mathrm{E}+01$ & $3.33 \mathrm{E}+01$ & $2.92 \mathrm{E}+01$ & $2.38 E+02$ \\
\hline QPSO & $3.48 \mathrm{E}+00$ & $1.51 \mathrm{E}+01$ & $5.49 \mathrm{E}+00$ & $2.94 \mathrm{E}+01$ \\
\hline BBBC & $1.99 \mathrm{E}+01$ & $4.23 \mathrm{E}+01$ & $9.64 \mathrm{E}+00$ & $5.99 E+01$ \\
\hline DS & $3.09 \mathrm{E}+01$ & $4.16 \mathrm{E}+01$ & $7.29 \mathrm{E}+00$ & $4.89 \mathrm{E}+01$ \\
\hline \multicolumn{5}{|c|}{$f_{2}$ Sphere } \\
\hline GBEST & $1.43 E-148$ & $4.21 \mathrm{E}-134$ & $1.76 \mathrm{E}-134$ & $8.45 \mathrm{E}-134$ \\
\hline BSA & $5.12 \mathrm{E}-10$ & 6.73E-09 & $5.65 \mathrm{E}-09$ & 3.32E-08 \\
\hline ITHS & $5.43 \mathrm{E}-06$ & $6.10 \mathrm{E}-02$ & $2.44 \mathrm{E}-02$ & $6.12 \mathrm{E}-02$ \\
\hline BAT & 4.72E-05 & $6.82 \mathrm{E}+00$ & $4.96 \mathrm{E}+00$ & $2.82 \mathrm{E}+01$ \\
\hline QPSO & $4.76 \mathrm{E}+00$ & $2.32 \mathrm{E}+01$ & $8.91 \mathrm{E}+00$ & $9.21 \mathrm{E}+01$ \\
\hline BBBC & 9.83E-05 & $2.47 \mathrm{E}-04$ & $3.89 \mathrm{E}-05$ & $4.82 \mathrm{E}-04$ \\
\hline DS & $7.15 \mathrm{E}+00$ & $2.70 \mathrm{E}+01$ & $5.53 \mathrm{E}+00$ & $3.62 \mathrm{E}+01$ \\
\hline \multicolumn{5}{|c|}{$f_{3}$ Ackley } \\
\hline GBEST & $3.99 E-15$ & $3.99 E-15$ & $0.00 \mathrm{E}+00$ & $3.99 \mathrm{E}-15$ \\
\hline BSA & $9.82 \mathrm{E}-08$ & $3.54 \mathrm{E}-07$ & $1.74 \mathrm{E}-07$ & $6.83 \mathrm{E}-07$ \\
\hline ITHS & $4.36 \mathrm{E}-04$ & $2.23 \mathrm{E}-01$ & $2.12 \mathrm{E}-01$ & $7.21 \mathrm{E}-01$ \\
\hline BAT & $2.73 E+01$ & $2.99 \mathrm{E}+01$ & $9.84 \mathrm{E}-01$ & $3.43 E+01$ \\
\hline QPSO & $2.31 \mathrm{E}+00$ & $9.52 \mathrm{E}+00$ & $3.65 \mathrm{E}+00$ & $2.37 \mathrm{E}+01$ \\
\hline BBBC & 4.19E-02 & $4.99 \mathrm{E}-02$ & $4.88 \mathrm{E}-03$ & $5.83 \mathrm{E}-02$ \\
\hline DS & $2.65 E+00$ & $2.22 \mathrm{E}+01$ & $2.20 \mathrm{E}+00$ & $2.67 \mathrm{E}+01$ \\
\hline \multicolumn{5}{|c|}{$f_{4}$ Griewank } \\
\hline GBEST & $0.00 \mathrm{E}+00$ & $0.00 \mathrm{E}+00$ & $0.00 \mathrm{E}+00$ & $0.00 \mathrm{E}+00$ \\
\hline BSA & 2.13E-09 & $5.76 \mathrm{E}-08$ & 7.89E-08 & $3.22 \mathrm{E}-07$ \\
\hline ITHS & $9.76 \mathrm{E}-08$ & 3.83E-03 & $1.90 \mathrm{E}-02$ & $7.70 \mathrm{E}-02$ \\
\hline BAT & $5.78 \mathrm{E}-01$ & $2.82 \mathrm{E}+00$ & 4.34E-01 & $5.66 \mathrm{E}+00$ \\
\hline QPSO & $2.17 \mathrm{E}-01$ & 8.73E-01 & 3.79E-01 & $2.41 \mathrm{E}+00$ \\
\hline BBBC & $3.12 \mathrm{E}-05$ & $3.22 \mathrm{E}-02$ & $2.99 \mathrm{E}-01$ & $4.66 \mathrm{E}-02$ \\
\hline DS & $8.76 \mathrm{E}-01$ & $2.75 \mathrm{E}+00$ & 5.32E-02 & $3.13 E+00$ \\
\hline \multicolumn{5}{|c|}{$f_{5}$ Rastrigin } \\
\hline GBEST & $0.00 \mathrm{E}+00$ & $2.22 \mathrm{E}-01$ & $5.98 \mathrm{E}-01$ & $3.65 E+00$ \\
\hline BSA & $8.23 \mathrm{E}-02$ & $2.93 E+00$ & $9.32 \mathrm{E}-01$ & $5.76 \mathrm{E}+00$ \\
\hline ITHS & $1.55 \mathrm{E}-04$ & $2.13 E+01$ & $2.43 \mathrm{E}+01$ & $8.91 E+01$ \\
\hline BAT & $7.98 \mathrm{E}+01$ & $1.21 \mathrm{E}+02$ & $4.71 \mathrm{E}+01$ & $3.87 \mathrm{E}+02$ \\
\hline QPSO & $1.03 E+01$ & $3.11 \mathrm{E}+01$ & $2.87 \mathrm{E}+01$ & $1.78 \mathrm{E}+02$ \\
\hline $\mathrm{BBBC}$ & $1.21 \mathrm{E}+02$ & $2.11 \mathrm{E}+02$ & $4.42 \mathrm{E}+01$ & $3.19 E+02$ \\
\hline DS & $1.54 \mathrm{E}+01$ & $1.81 \mathrm{E}+02$ & $1.88 \mathrm{E}+01$ & $2.82 \mathrm{E}+02$ \\
\hline \multicolumn{5}{|c|}{$f_{6}$ Zakharov } \\
\hline GBEST & 4.13E-26 & $1.87 \mathrm{E}-20$ & $2.91 \mathrm{E}-20$ & 8.93E-20 \\
\hline BSA & $1.21 \mathrm{E}+01$ & $2.74 \mathrm{E}+01$ & $5.51 \mathrm{E}+00$ & $3.13 E+01$ \\
\hline ITHS & $3.53 \mathrm{E}-07$ & $3.98 E-02$ & 8.69E-02 & $4.74 \mathrm{E}-01$ \\
\hline BAT & $9.11 \mathrm{E}+00$ & $4.62 \mathrm{E}+02$ & $1.87 \mathrm{E}+03$ & $8.14 E+03$ \\
\hline QPSO & $1.35 \mathrm{E}+01$ & $6.21 \mathrm{E}+01$ & $4.71 \mathrm{E}+01$ & $1.98 \mathrm{E}+02$ \\
\hline
\end{tabular}


O.E. Turgut, Multi-Objective Thermal Design of a Shell and Tube Condenser through Global Best Algorithm

\begin{tabular}{|c|c|c|c|c|}
\hline $\mathrm{BBBC}$ & $5.73 \mathrm{E}-02$ & $7.21 \mathrm{E}+01$ & $5.82 \mathrm{E}+01$ & $3.63 \mathrm{E}+02$ \\
\hline DS & $2.13 \mathrm{E}+01$ & $6.75 \mathrm{E}+01$ & $2.32 \mathrm{E}+01$ & $2.49 \mathrm{E}+02$ \\
\hline \multicolumn{5}{|c|}{$f_{7}$ Alpine } \\
\hline GBEST & 1.12E-93 & $3.22 \mathrm{E}-06$ & $1.12 \mathrm{E}-05$ & 7.38E-05 \\
\hline BSA & 7.85E-04 & 2.13E-03 & $1.62 \mathrm{E}-03$ & 6.83E-03 \\
\hline ITHS & $6.55 \mathrm{E}-05$ & 7.32E-02 & 2.17E-01 & $1.61 \mathrm{E}+00$ \\
\hline BAT & $2.95 \mathrm{E}+00$ & $1.68 \mathrm{E}+01$ & $5.93 E+00$ & $3.19 \mathrm{E}+01$ \\
\hline QPSO & $1.04 \mathrm{E}+00$ & $4.36 \mathrm{E}+00$ & $2.23 \mathrm{E}+00$ & $1.03 E+01$ \\
\hline BBBC & $3.02 \mathrm{E}+00$ & $8.24 \mathrm{E}+00$ & $3.36 \mathrm{E}+00$ & $2.17 \mathrm{E}+01$ \\
\hline DS & $1.13 \mathrm{E}+01$ & $1.73 \mathrm{E}+01$ & $2.53 \mathrm{E}+00$ & $2.32 \mathrm{E}+01$ \\
\hline \multicolumn{5}{|c|}{$f_{8}$ Penalized 1} \\
\hline GBEST & 9.19E-15 & $2.42 \mathrm{E}-10$ & 8.49E-10 & 8.36E-09 \\
\hline BSA & 8.12E-11 & $2.48 \mathrm{E}-10$ & 2.71E-11 & 4.86E-07 \\
\hline ITHS & $2.74 \mathrm{E}-06$ & $3.43 \mathrm{E}-04$ & $2.25 \mathrm{E}-04$ & 8.36E-04 \\
\hline BAT & 2.72E-01 & 8.61E-01 & 4.84E-01 & $2.26 \mathrm{E}+00$ \\
\hline QPSO & $3.61 \mathrm{E}-02$ & 4.93E-01 & 2.51E-01 & 8.81E-01 \\
\hline BBBC & $3.68 \mathrm{E}-02$ & 7.31E-01 & 4.62E-01 & $2.86 \mathrm{E}+00$ \\
\hline DS & $3.42 \mathrm{E}-01$ & 8.63E-01 & $3.72 \mathrm{E}-01$ & $2.83 \mathrm{E}+00$ \\
\hline \multicolumn{5}{|l|}{ f9 Step } \\
\hline GBEST & $4.68 \mathrm{E}-11$ & $3.48 \mathrm{E}-10$ & $2.12 \mathrm{E}-10$ & $4.93 \mathrm{E}-10$ \\
\hline BSA & $3.92 \mathrm{E}-10$ & 4.65E-09 & 2.13E-09 & 2.79E-08 \\
\hline ITHS & $1.89 \mathrm{E}-06$ & 8.88E-03 & 8.92E-03 & 4.84E-02 \\
\hline BAT & $2.42 \mathrm{E}-05$ & $4.44 \mathrm{E}+00$ & $4.79 E+00$ & $1.76 \mathrm{E}+01$ \\
\hline QPSO & $3.58 \mathrm{E}+00$ & $2.48 \mathrm{E}+01$ & $7.33 \mathrm{E}+00$ & $4.25 E+01$ \\
\hline BBBC & $6.16 \mathrm{E}-05$ & $1.72 \mathrm{E}-04$ & $1.92 \mathrm{E}-04$ & $1.76 \mathrm{E}-03$ \\
\hline DS & $8.23 E+00$ & $2.65 \mathrm{E}+01$ & $6.47 \mathrm{E}+00$ & $4.29 \mathrm{E}+01$ \\
\hline \multicolumn{5}{|c|}{$f_{10}$ Schwefel 2.22} \\
\hline GBEST & 3.87E-99 & 5.79E-93 & $1.94 \mathrm{E}-92$ & 8.37E-92 \\
\hline BSA & $2.86 \mathrm{E}-05$ & 5.12E-05 & 1.83E-05 & 8.74E-05 \\
\hline ITHS & $4.76 \mathrm{E}-02$ & 3.85E-01 & 7.96E-01 & $2.87 \mathrm{E}+00$ \\
\hline BAT & $6.09 \mathrm{E}+00$ & $7.23 \mathrm{E}+01$ & $2.84 \mathrm{E}+01$ & $9.88 \mathrm{E}+01$ \\
\hline QPSO & $5.83 E+00$ & $9.99 E+00$ & $3.56 \mathrm{E}+00$ & $2.98 \mathrm{E}+01$ \\
\hline BBBC & $4.23 E+00$ & $5.73 E+01$ & $6.97 \mathrm{E}+02$ & $7.63 E+03$ \\
\hline DS & $9.94 \mathrm{E}+00$ & $1.21 \mathrm{E}+01$ & $2.80 \mathrm{E}+00$ & $2.52 \mathrm{E}+01$ \\
\hline
\end{tabular}


O.E. Turgut, Multi-Objective Thermal Design of a Shell and Tube Condenser through Global Best Algorithm

Table 2. Numerical formulations of the optimization benchmark functions

\begin{tabular}{|c|c|}
\hline & Function \\
\hline Levy & $\begin{aligned} f_{1}(x)= & \sin ^{2}\left(\pi w_{1}\right)+\sum_{i=1}^{D-1}\left(w_{i}-1\right)^{2}\left[1+10 \sin ^{2}\left(\pi w_{i}+1\right)\right]+\left(w_{D}-1\right)^{2}\left[1+\sin ^{2}\left(2 \pi w_{D}\right)\right] \\
& w_{i}=1+\frac{x_{i}-1}{4}, \text { for } i=1, . ., D\end{aligned}$ \\
\hline Sphere & $f_{2}(x)=\sum_{i=1}^{D} x_{i}^{2}$ \\
\hline Ackley & $f_{3}(x)=-20 \exp \left(-0.2 \sqrt{\frac{1}{D} \sum_{i=1}^{D} x_{i}^{2}}\right)-\exp \left(\frac{1}{D} \sum_{i=1}^{D} \cos \left(2 \pi x_{i}\right)\right)+20+\exp (1)$ \\
\hline Griewank & $f_{4}(x)=\sum_{i=1}^{D-1}\left(100\left(x_{i+1}-x_{i}^{2}\right)^{2}+\left(x_{i}-1\right)^{2}\right)$ \\
\hline Rastrigin & $f_{5}(x)=\sum_{i=1}^{D}\left(x_{i}^{2}-10 \cos \left(2.0 \pi x_{i}\right)\right)+10 D$ \\
\hline Zakharov & $f_{6}(x)=\sum_{i=1}^{D} x_{i}^{2}+\left(\sum_{i=1}^{D} 0.5 i x_{i}\right)^{2}+\left(\sum_{i=1}^{D} 0.5 i x_{i}\right)^{4}$ \\
\hline Alpine & $f_{7}(x)=\sum_{i=1}^{D} x_{i} \sin \left(x_{i}\right)+0.1 x_{i} \mid$ \\
\hline Penalized & $\begin{aligned} f_{8}(x)= & \frac{\pi}{D}\left\{10 \sin ^{2}\left(\pi y_{1}\right)+\sum_{i=1}^{D-1}\left(y_{i}-1\right)^{2}\left[1+10 \sin ^{2}\left(\pi y_{i+1}\right)\right]+\left(y_{D}-1\right)^{2}\right\} \\
& +\sum_{i=1}^{D} u\left(x_{i}, 10,100,4\right)\end{aligned}$ \\
\hline Step & $f_{9}(x)=\sum_{i=1}^{D}\left(\left\lfloor x_{i}+0.5\right\rfloor\right)^{2}$ \\
\hline $\begin{array}{l}\text { Schfewel } \\
2.22\end{array}$ & $f_{10}(x)=\sum_{i=1}^{D}\left|x_{i}\right|+\prod_{i=1}^{D}\left|x_{i}\right|$ \\
\hline
\end{tabular}


O.E. Turgut, Multi-Objective Thermal Design of a Shell and Tube Condenser through Global Best Algorithm

\section{Numerical Results}

\subsection{Single objective optimization}

This study considers Global Best Algorithm to optimize a shell and tube condenser from thermoeconomic and overall heat transfer coefficient points of view. A case study adopted from Kakaç et al.[2] is solved by Global Best Algorithm (GBEST) along with widely accepted metaheuristic algorithms of Particle Swarm Optimization (PSO) [42] and Differential Evolution (DE) [43] in order to validate the efficiency and the accuracy the proposed method. Perturbation schemes and manipulation equations those established the basics of the proposed GBEST optimizer will not be discussed and explained in this study due to the space restricitions imposed. Interested readers could find the fundamentals of the mentioned GBEST method in Turgut and Coban [45] with given detailed insights and explanataions. Pitch ratio $\left(\mathrm{p}_{\mathrm{r}}\right)$, In tube flow velocity $(\mathrm{v})$, type of tube arrangement $\left(30^{\circ}-60^{\circ}\right.$ or $\left.45^{\circ}-90^{\circ}\right)$, and tube outer diameter $\left(\mathrm{d}_{\text {out }}\right)$ are selected design variables to be adjusted iteratively by virtue of GBEST as well as remaining optimizers mentioned above. Table 3 lists the operational conditions as well as the physical properties of the working fluids occupied in shell and tube sides.

Table 3. Thermophysical properties of the working fluids

\begin{tabular}{lll}
\hline & $\begin{array}{l}\text { Shell side - } \\
\text { steam to liquid }\end{array}$ & Tube side - water \\
\hline$\dot{\mathrm{m}}(\mathrm{kg} / \mathrm{s})$ & 215.68 & 10717.4 \\
$\mathrm{~T}_{\text {inlet }}\left({ }^{\circ} \mathrm{C}\right)$ & 45.8 & 25 \\
$\mathrm{~T}_{\text {outlet }}\left({ }^{\circ} \mathrm{C}\right)$ & 45.8 & 30 \\
$\rho\left(\mathrm{kg} / \mathrm{m}^{3}\right)$ & 990.0 & 997.0 \\
$\mu(\mathrm{Pa} . \mathrm{s})$ & 0.000588 & 0.00098 \\
$\mathrm{C}_{\mathrm{p}}(\mathrm{J} / \mathrm{kgK})$ & 4182 & 4180 \\
$\mathrm{k}(\mathrm{W} / \mathrm{mK})$ & 0.635 & 0.602 \\
$\mathrm{~h}_{\mathrm{fg}}(\mathrm{kJ} / \mathrm{kg})$ & 2392.0 & 2409.1 \\
$\mathrm{R}_{\mathrm{f}}\left(\mathrm{m}^{2} \mathrm{~K} / \mathrm{W}\right)$ & 0.00009 & 0.00018 \\
\hline
\end{tabular}

Table 4 reports the upper and lower bounds of the optimized design parameters. 50 algorithm runs with 100000 function evaluation have been made for each compared optimizer due to their intrinsic stochastic nature. Mentioned algorithms have been developed in Java and run on a laptop computer with a dual core processor with $2.0 \mathrm{GHz}$ having $4.0 \mathrm{~GB}$ RAM. Parameters for estimating the operational as well as investment costs are considered as the following [2,32]: equipment life (ny) $=10$, annual discounted rate $(\mathrm{i})=10 \%$, cost of electricity $\left(c_{\mathrm{el}}\right)=20 \$ / \mathrm{MWh}$, pump efficiency $\left(\eta_{\mathrm{p}}\right)=0.85$, and active hours of operation in a year $(\tau)=5000 \mathrm{~h} /$ year.

Table 4. Upper and lower bounds for the optimized design variables

\begin{tabular}{llc}
\hline Optimized parameters & Upper & Lower \\
\hline $\mathrm{d}_{\text {out }}(\mathrm{mm})$ & 18.000 & 30.000 \\
$\mathrm{p}_{\mathrm{r}}$ & 1.250 & 1.500 \\
$\mathrm{v}(\mathrm{m} / \mathrm{s})$ & 1.200 & 3.000 \\
Tube arrangement & $30^{\circ}-60^{\circ}$ or $45^{\circ}-90^{\circ}$ \\
\hline
\end{tabular}


Table 5 presents the optimum solution found by three optimization algorithms acompannied with the preiminary design accomplished in Kakac et al.[2] for minimum total cost of heat exchanger. One can see the huge reduction (20135.664 \$) in total cost of heat transfer when GBEST algorithm is applied on to design parameters. This decrease is primarily caused by the decrease in-tube outer diameter (29.1\%) and in-tube flow velocity (25.5\%). Reynolds number for in-tube flow becomes less by $53 \%$ than the primer design which directly leads to a total decrease $(15.5 \%)$ in convective heat transfer coefficient for in-tube flow. Apart from that, decrement in outer tube has a great role in the increase of shell side heat tranfer coefficient at the tube inlet (12.4\%) and outlet (11.2\%). However, cumulative effect of the increase in shell side and decrease in tube side heat transfer coefficient rates result in a reduction $(8.7 \%)$ in average overall heat transfer coefficient which also gives a similar level of rise to the total heat exchange area (8.7\%). Pitch ratio has slight effect on the design values of shell diameter and number of tubes in a vertical column. These parameters get their optimum values while pitch ratio is at its lower limit of 1.250. As can be seen from Eq.(19) to Eq.(22), pressure drop is mainly related with variable values of intube flow velocity and tube outer diameters. Their cumulative influences on pressure drop rates cause a considerable decrease in pumping power (51.1\%) that cause a marked discount in operational cost. Nevertheless, increase in investment $\operatorname{cost}(8.1 \%)$ conduced by the increment in total heat exchange area hampers the reduction in total cost of heat exchanger. In addition, it is observable that GBEST outperforms the other compared methods including PSO and $\mathrm{DE}$ with regards to the best results of optimal total cost.

Table 5. Optimization of design variables with respect to minimum total cost of heat exchanger

\begin{tabular}{lllll}
\hline Design parameters & $\begin{array}{l}\text { Preliminary } \\
\text { design }\end{array}$ & GBEST & DE & PSO \\
\hline $\mathrm{d}_{\text {out }}(\mathrm{mm})$ & 25.400 & 18.000 & 18.000 & 18.000 \\
$v(\mathrm{~m} / \mathrm{s})$ & 2.000 & 1.489 & 1.578 & 1.577 \\
$\mathrm{pr}(-)$ & 1.500 & 1.250 & 1.276 & 1.354 \\
Tube arrangement, $(-)$ & $45^{\circ}-90^{\circ}$ & $30^{\circ}-60^{\circ}$ & $30^{\circ}-60^{\circ}$ & $30^{\circ}-60^{\circ}$ \\
\hline $\mathrm{d}_{\text {in }}(\mathrm{mm})$ & 22.910 & 14.400 & 14.400 & 14.400 \\
$\mathrm{~L}(\mathrm{~m})$ & 12.862 & 5.853 & 6.126 & 6.126 \\
$\mathrm{D}_{\mathrm{s}}(\mathrm{m})$ & 5.093 & 5.172 & 5.130 & 5.445 \\
$\mathrm{~N}_{\mathrm{T}}(-)$ & 13038 & 44313 & 41810 & 41840 \\
$\mathrm{Re}_{\mathrm{c}}$ & 46614.836 & 21821 & 23127.621 & 23113.084 \\
$\mathrm{n}(-)$ & 77 & 87 & 86 & 87 \\
$\mathrm{~h}_{\text {tube }}\left(\mathrm{W} / \mathrm{m}^{2} \mathrm{~K}\right)$ & 8095.760 & 6835.976 & 7173.403 & 7169.148 \\
$\mathrm{~h}_{\text {in }}\left(\mathrm{W} / \mathrm{m}^{2} \mathrm{~K}\right)$ & 5434.514 & 6109.010 & 6099.545 & 6085.361 \\
$\mathrm{U}_{\text {in }}\left(\mathrm{W} / \mathrm{m}^{2} \mathrm{~K}\right)$ & 1606.905 & 1471.522 & 1489.822 & 1488.745 \\
$\mathrm{~h}_{\text {out }}\left(\mathrm{W} / \mathrm{m}^{2} \mathrm{~K}\right)$ & 6310.722 & 7111.427 & 7099.322 & 7082.688 \\
$\mathrm{U}_{\text {out }}\left(\mathrm{W} / \mathrm{m}^{2} \mathrm{~K}\right)$ & 1675.697 & 1523.240 & 1542.891 & 1541.858 \\
$\mathrm{U}_{\text {aver }}\left(\mathrm{W} / \mathrm{m}^{2} \mathrm{~K}\right)$ & 1641.301 & 1497.381 & 1516.357 & 1515.302 \\
$\mathrm{~A}_{\text {eff }}\left(\mathrm{m}{ }^{2}\right)$ & 13381.713 & 14667.88 & 14484.334 & 14494.418 \\
$\Delta \mathrm{p}_{\text {tot }}(\mathrm{Pa})$ & 31971.28 & 15640.702 & 18004.242 & 17980.107 \\
$\mathrm{PP}(\mathrm{kW})$ & 404.329 & 197.800 & 227.693 & 227.388 \\
$\mathrm{C}_{\text {oper }}(\$)$ & 248442.981 & 121541.024 & 139907.661 & 139720.110 \\
$\mathrm{C}_{\text {inv }}(\$)$ & 1324507.224 & 1431273.515 & 1416125.363 & 1416958.311 \\
\hline $\mathrm{C}_{\text {total }}(\$)$ & 1572950.204 & 1552814.539 & 1556033.029 & 1556678.422 \\
\hline
\end{tabular}


Figure 1 visualizes the convergence histories of the compared optimizers. As it is seen, GBEST reaches its optimum more quicker than the other methods.

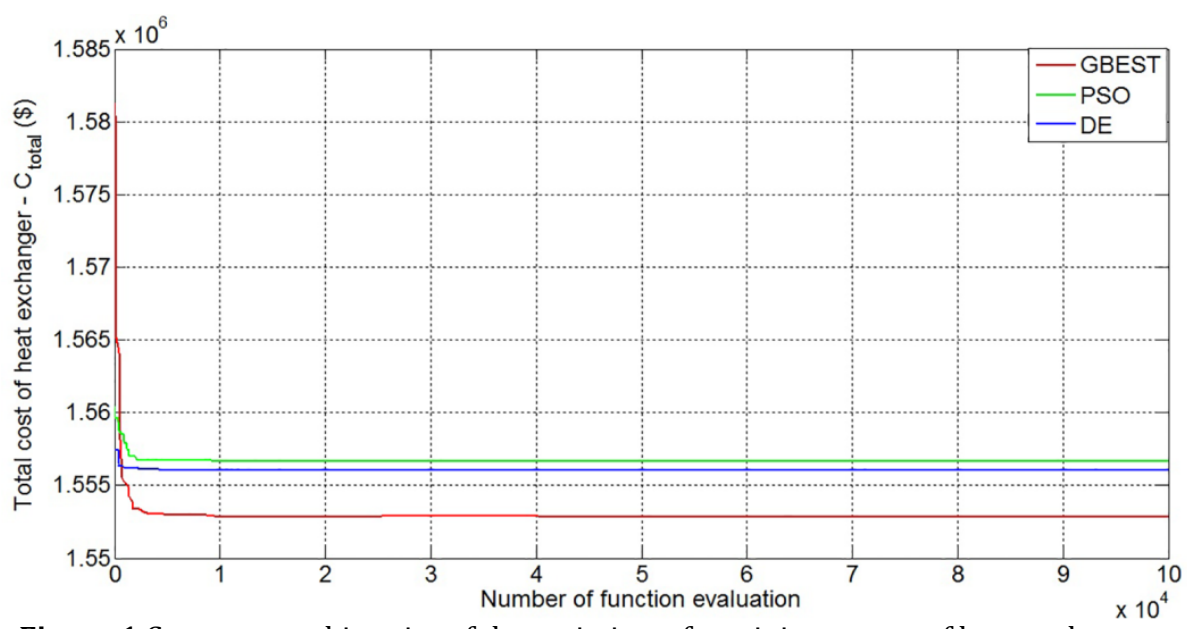

Figure 1 Convergence histories of the optimizers for minimum cost of heat exchanger

Table 6 compares the optimum results found by three optimizers along with the original study taken by Kakac et al.[2] for maximum average overall heat transfer coefficient. It is seen that when using GBEST in optimization process, average overall heat transfer coefficient rates has increased to some extent (by $4.6 \%)$. This small increase is due to the increase in in-tube flow velocity which hits the its allowable upper limits and decrease in outer tube diamaters which also reaches its predefined lower bound limits. This combinatorial relationship between two design parameters leads to a considerable increase (\%51.3) in convective heat transfer coefficient for tube side. Reduction in tube diameters conduce a remarkable increase in heat transfer coefficients for tube inlet $(16.1 \%)$ and outlet $(16.3 \%)$ that directly influences the overall heat transfer heat transfer coefficients rates. It is also revealed that utilization of PSO and DE methods is beneficial in thermal design of a shell and tube condenser based on the significant improvement on the heat transfer coefficient rates. Figure 2 compares the convergence characteristics of the mentioned optimizers. Each optimization algorithm nearly shows the similar convergence behaviour such that deep gradual increases at the early phase of the iterations is followed by stagnant continuation which prevails through the end of iterations. 
O.E. Turgut, Multi-Objective Thermal Design of a Shell and Tube Condenser through Global Best Algorithm

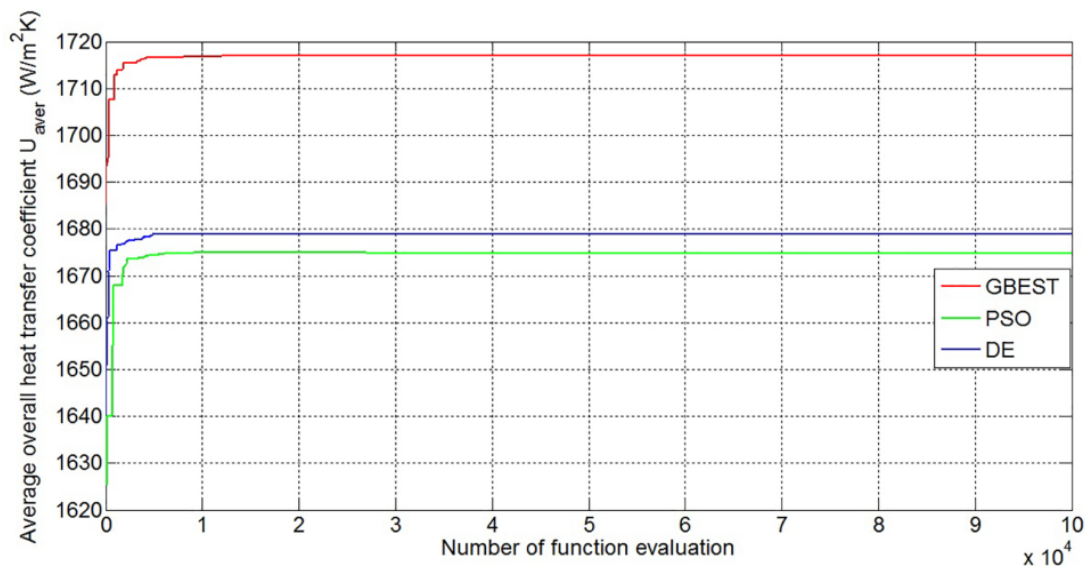

Figure 2 Evolution characteristics of the objective function for compared algorithms for maximum average overall heat transfer coefficients

Table 6 Optimum design parameters for maximum average overall heat transfer coefficient

\begin{tabular}{lllll}
\hline Design parameters & $\begin{array}{l}\text { Preliminary } \\
\text { design }\end{array}$ & GBEST & DE & PSO \\
\hline $\mathrm{d}_{\text {out }}(\mathrm{mm})$ & 25.400 & 18.040 & 18.000 & 18.000 \\
$v(\mathrm{~m} / \mathrm{s})$ & 2.000 & 3.000 & 2.999 & 2.999 \\
$\mathrm{p}_{\mathrm{r}}(-)$ & 1.500 & 1.250 & 1.292 & 1.404 \\
Tube arrangement $(-)$ & $45^{\circ}-90^{\circ}$ & $30^{\circ}-60^{\circ}$ & $45^{\circ}-90^{\circ}$ & $45^{\circ}-90^{\circ}$ \\
\hline $\mathrm{d}_{\text {in }}(\mathrm{mm})$ & 22.910 & 14.436 & 14.400 & 14.400 \\
$\mathrm{~L}(\mathrm{~m})$ & 12.862 & 10.303 & 10.514 & 10.537 \\
$\mathrm{D}_{\mathrm{s}}(\mathrm{m})$ & 5.093 & 3.644 & 4.040 & 4.390 \\
$\mathrm{~N}_{\mathrm{T}}(-)$ & 13038 & 21891.004 & 21999 & 22001 \\
$\mathrm{Re}_{\mathrm{c}}$ & $46,614.836$ & 44060.463 & 43592.111 & 43949.742 \\
$\mathrm{n}(-)$ & 77 & 61 & 94 & 98 \\
$\mathrm{~h}_{\text {tube }}\left(\mathrm{W} / \mathrm{m}^{2} \mathrm{~K}\right)$ & 8095.760 & 12253.445 & 12258.198 & 12258.400 \\
$\mathrm{~h}_{\text {in }}\left(\mathrm{W} / \mathrm{m}^{2} \mathrm{~K}\right)$ & 5434.514 & 6313.334 & 5785.545 & 5736.937 \\
$\mathrm{U}_{\text {in }}\left(\mathrm{W} / \mathrm{m}^{2} \mathrm{~K}\right)$ & 1606.905 & 1685.001 & 1645.177 & 1641.231 \\
$\mathrm{~h}_{\text {out }}\left(\mathrm{W} / \mathrm{m}^{2} \mathrm{~K}\right)$ & 6310.722 & 7340.658 & 6721.731 & 6664.746 \\
$\mathrm{U}_{\text {out }}\left(\mathrm{W} / \mathrm{m}^{2} \mathrm{~K}\right)$ & 1675.697 & 1750.378 & 1713.019 & 1709.303 \\
$\left.\mathrm{~A}_{\text {eff }}(\mathrm{m})^{2}\right)$ & 13381.713 & 12786.608 & 13080.489 & 13110.403 \\
$\Delta \mathrm{p}_{\text {tot }}(\mathrm{Pa})$ & 31971.28 & 87358.383 & 88987.070 & 89152.043 \\
$\mathrm{PP}_{(\mathrm{kW})}$ & 404.329 & 1104.790 & 1125.387 & 1127.474 \\
$\mathrm{C}_{\text {oper }}(\$)$ & 248442.981 & 678845.957 & 691502.186 & 692784.162 \\
$\mathrm{C}_{\text {inv }}(\$)$ & 1324507.224 & 1274592.308 & 1299284.365 & 1301793.074 \\
$\mathrm{C}_{\text {total }}(\$)$ & 1572950.204 & 1953438.266 & 1990786.552 & 1994577.237 \\
\hline $\mathrm{U}_{\text {aver }}\left(\mathrm{W} / \mathrm{m}^{2} \mathrm{~K}\right)$ & 1641.301 & 1717.689 & 1679.098 & 1675.267 \\
\hline & & & & \\
\hline
\end{tabular}




\subsection{Multi objective optimization}

Conflicting yet completing tendencies of objective functions necessitates the implementing multi objective optimization resulting in construction of a Pareto frontier which is comprised of a set of non-dominated solutions. Multi objective optimization is a kind of decision making theory which is shaped by the related problem objectives to be optimized simultaneously. As mentioned, multi objective optimization yields Pareto solutions that constructs the Pareto curve. It can also be said that a favorable trade-off between the results of contradictive objectives is called Pareto optimum solution. Figure 3 shows the Pareto frontier constructed by the dual objective optimization of abovementioned problem objectives along with optimal solutions found by three different decision making theories. Table 7 reports the optimum solutions acquired by the decision making methods of LINMAP, TOPSIS, and Shannon's entropy theory. In the context of multi objective optimization, selection of the most favourable solution among bunch of nondominated optimal solutions forms the main and essential part of the decision process. There are several decision making theories that are used in decision problems. These methods can also be employed for choosing the final optimum solution from the set of nondominated solutions constructing Pareto frontier. This study considers the most three distinguished decision making theories of LINMAP, TOPSIS and Shannon's entropy theory and the final optimal solution is obtained from the outcomes of these decision making methods. Formulations and detailed description of these methods are not given in this study due to the restricted space limitations. Interested readers could find more about these methods in Arora et al. [46]. In addition, it is noteworthy to mention the importance of the term called "deviation index" given in Table 7 . This term represents the feasibilty of the solution selected by a decision making theory. It is evaluated such that the more smaller deviation index valued solution, the more suitable and feasible solution it is. In the light of this definition, optimal solution found by LINMAP and TOPSIS is more relevant than that obtained by Shannon's entropy theory. The optimal values of average overall heat transfer coefficient and total cost of heat exchanger are respectively $1497.066 \mathrm{~W} / \mathrm{m}^{2} \mathrm{~K}$ and $1552889.975 \$$. Figure 4 shows the scatter plot of four design parameters obtained from the Pareto frontier. It is more explanatory to visualize the behavior of the decision variables in a scatter representation. It displays that pitch ratio and outer tube diameter reach their minimum value while variations have been observed for intube flow velocities. Tube arrangement is found to be $30^{\circ}-60^{\circ}$ design pattern for each solution on the frontier. 
O.E. Turgut, Multi-Objective Thermal Design of a Shell and Tube Condenser through Global Best Algorithm

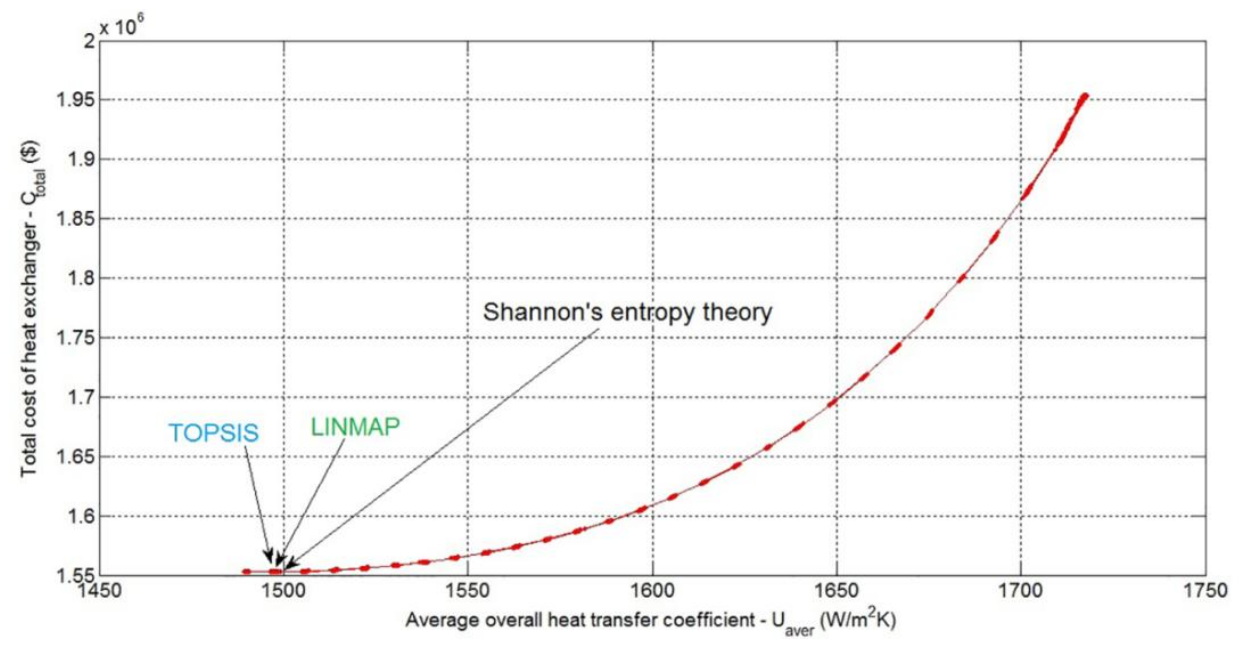

Figure 3. Pareto frontier for two conflicting objectives and optimum solutions obtained by LINMAP, TOPSIS, and Shannon's entropy theory

Table 7. Optimum solutions found by different decision making methods

\begin{tabular}{llll}
\hline Design parameters & TOPSIS & LINMAP & Shannon's entropy theory \\
\hline $\mathrm{d}_{\text {out }}(\mathrm{mm})$ & 18.010 & 18.010 & 18.005 \\
$\mathrm{v}(\mathrm{m} / \mathrm{s})$ & 1.488 & 1.488 & 1.457 \\
$\mathrm{p}_{\mathrm{r}}(-)$ & 1.250 & 1.250 & 1.251 \\
Tube arrangement, $(-)$ & $30^{\circ}-60^{\circ}$ & $30^{\circ}-60^{\circ}$ & $30^{\circ}-60^{\circ}$ \\
\hline $\mathrm{d}_{\text {in }}(\mathrm{mm})$ & 14.408 & 14.408 & 14.404 \\
$\mathrm{~L}(\mathrm{~m})$ & 5.854 & 5.854 & 5.757 \\
$\mathrm{D}_{\mathrm{s}}(\mathrm{m})$ & 5.175 & 5.175 & 5.234 \\
$\mathrm{~N}_{\mathrm{T}}(-)$ & 44285 & 44285 & 45272 \\
$\mathrm{Re}_{\mathrm{c}}$ & 21821.412 & 21821.412 & 21351.72 \\
$\mathrm{n}(-)$ & 87 & 87 & 88 \\
$\mathrm{~h}_{\text {tube }}\left(\mathrm{W} / \mathrm{m}^{2} \mathrm{~K}\right)$ & 6831.881 & 6831.881 & 6711.812 \\
$\mathrm{~h}_{\text {in }}\left(\mathrm{W} / \mathrm{m}^{2} \mathrm{~K}\right)$ & 6108.203 & 6108.203 & 6103.418 \\
$\mathrm{U}_{\text {in }}\left(\mathrm{W} / \mathrm{m}^{2} \mathrm{~K}\right)$ & 1471.215 & 1471.215 & 1463.900 \\
$\mathrm{~h}_{\text {out }}\left(\mathrm{W} / \mathrm{m}^{2} \mathrm{~K}\right)$ & 7110.493 & 7110.493 & 7105.248 \\
$\mathrm{U}_{\text {out }}\left(\mathrm{W} / \mathrm{m}^{2} \mathrm{~K}\right)$ & 1522.918 & 1522.918 & 1515.137 \\
$A_{\text {eff }}\left(\mathrm{m}^{2}\right)$ & 14670.975 & 14670.975 & 14745.31 \\
$\mathrm{p}_{\text {tot }}(\mathrm{Pa})$ & 15617.655 & 15617.655 & 14832.37 \\
$\mathrm{PP}(\mathrm{kW})$ & 197.510 & 197.510 & 187.579 \\
$\mathrm{C}_{\text {oper }}(\$)$ & 121361.936 & 121361.936 & 115259.644 \\
$\mathrm{C}_{\text {inv }}(\$)$ & 1431528.038 & 1431528.038 & 1437654.779 \\
\hline $\mathrm{C}_{\text {total }}(\$)$ & 1552889.975 & 1552889.975 & 1552914.423 \\
\hline $\mathrm{U}_{\text {aver }}\left(\mathrm{W} / \mathrm{m}^{2} \mathrm{~K}\right)$ & 1497.066 & 1497.066 & 1489.519 \\
\hline Deviation index & 0.1284 & 0.1284 & 0.1376 \\
\hline
\end{tabular}



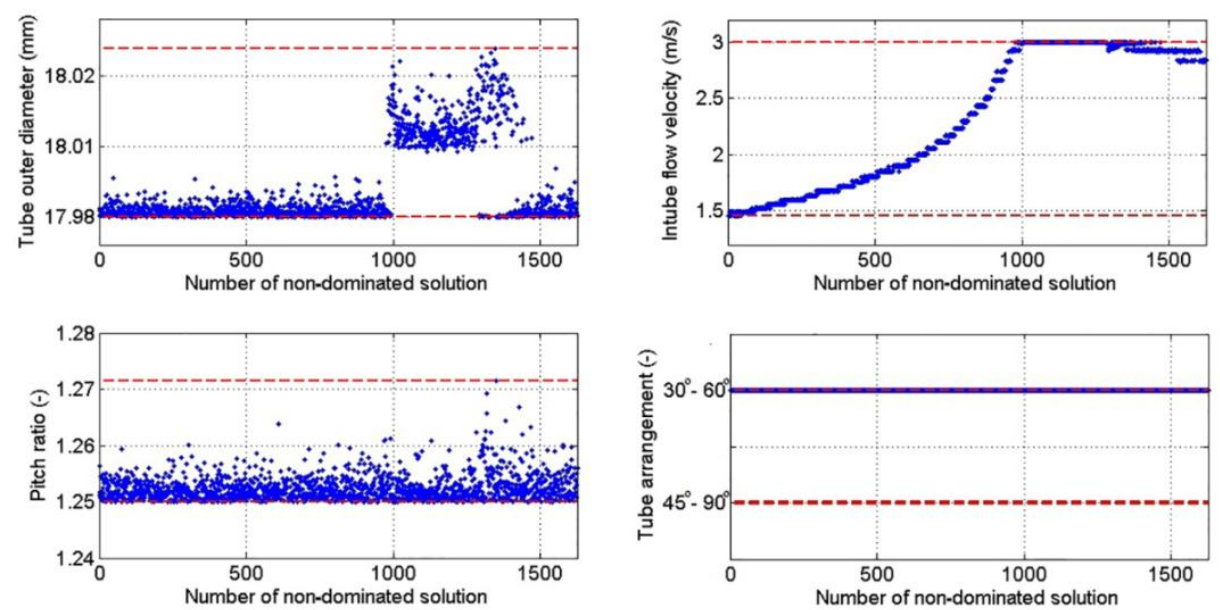

Figure 4. Distribution of the design parameters with the number of non-dominated solutions on the Pareto frontier.

\section{Sensitivity Analysis}

Variational effects of four design variables on the problem objectives of average overall heat transfer coefficient rates and total cost of heat exchanger is visually shown in Figure 5(a-d). Best solutions selected by TOPSIS and LINMAP are considered for evaluation of influences of design parameters over problem objectives. The remaning parameters stays constant during evaluations. It can be clearly observed that any increase in tube outer diameters leads to a decrease in average overall heat transfer coefficient rates while giving rise to total cost. Increment in tube velocity values cause an increase both total cost and heat transfer coefficent rates which is resulted by the increase in Reynolds number along with the total pressure drop rates those having direct relationship with heat transfer coefficient and total cost, respectively. As can be seen from Figure 5(c), pitch ratio has negligible effect on the problem objectives when compared to the impact made by the other design variables. However, increase in pitch ratio values adversely affects both heat transfer coefficient and total cost. As previously discussed and can be seen from Figure 5(d), best system performance is obtained when $30^{\circ}-60^{\circ}$ tube arrangement is maintained. 

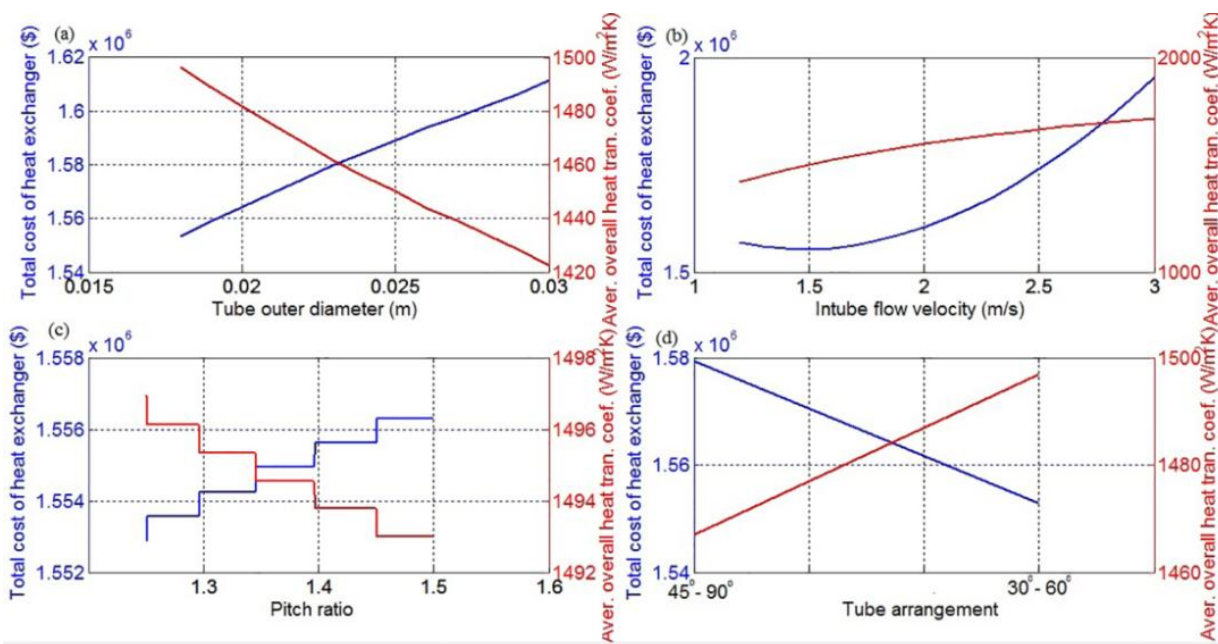

Figure 5. Influences of considered design parameters over problem objectives

\section{Conclusion}

This study utilizes Global Best Algorithm (GBEST) in order to optimize the system parameters of a shell and tube condenser with such an aim to obtain its total minimum cost as well as to attain maximum average overall heat transfer coefficient in a separate and simultaneous manner. Ten different optimization benchmark functions have been utilized to assess the performance of the proposed GBEST and numerical outcomes have been compared with literature optimizers. GBEST surpassed the compared optimization methods in terms of solution accuracy and stability. Efficiency of the solutions found by GBEST are compared against the case study taken from literature and numerical outcomes of the highly reputed optimization algorithms of Differential Evolution and Particle Swarm Optimization. The pareto frontier for dual objectives is plotted and best solution among non-dominated optimum solutions is selected through the decision making theories of LINMAP, TOPSIS, and Shannon's entropy theory. It is seen that optimum solution obtained by TOPSIS and LINMAP is more feasible than that found by Shannon's entropy theory according to the deviation index values. All in all, GBEST proves its superiority over compared algorithms and shows that its application on single and multiobjective optimization problems yields very favourable results both terms of solution efficiency and effectivity.

\section{References}

[1] Asadi, M., Song, Y., Sunden, B, Xie, G. 2014. Economic optimization design of shell and tube heat exchangers by a cuckoo search algorithm, Applied Thermal Engineering, Vol.73, pp.1032 1040.

[2] Kakaç, S., Liu, H., Pramuanjaroenkij, A. 2012. Heat Exchangers Selection, Rating, and Thermal Design, Boca Raton: Taylor and Francis, 102p.

[3] Kern, D.Q. 1950.Process Heat Transfer, McGraw-Hill, p.305.

[4] Rosenhow, W.M., Hartnett, P.J. 1973. Handbook of Heat Transfer, McGraw-Hill, 467p.

[5] Shah, R.K., Bell, K.J. 2000. The CRC Handbook of Thermal Engineering, CRC Press, 372p. 
O.E. Turgut, Multi-Objective Thermal Design of a Shell and Tube Condenser through Global Best Algorithm

[6] Fabbri, G. 2000. Heat transfer optimization in corrugated wall channels, International Journal of Heat and Mass Transfer, Vol. 43, pp.4299 - 4310 .

[7] Bintoro, J.S., Akbarzadeh, A., Mochizuki, M. 2005. A closed-loop electronics cooling by implementing single phase impinging jet and mini channels heat exchanger, Applied Thermal Engineering, Vol.25, pp.2740 2753.

[8] Mariani, V.C., Duck, A.R.K., Guerra, F.A., Coelho, L.S., Rao, R.V. 2012. A chaotic quantum-behaved particle swarm approach applied to optimization of heat exchangers, Applied Thermal Engineering, Vol.42, pp.119-128.

[9] Mohanty, D.K. 2016. Application of firefly algorithm for design optimization of a shell and tube heat exchanger from economic point of view, Intenational Journal of Thermal Sciences, Vol. 102, pp.228 - 238.

[10] Caputo, A.C., Pelagagge, P.M., Salini, P. 2008. Heat exchanger design based on economic optimization, Applied Thermal Engineering, Vol.28, pp.1151 - 1159.

[11] Hadidi, A., Hadidi, M., Nazaifi, A. 2013. A new design approach for shell and tube heat exchangers using imperialist competitive algorithm (ICA) from economic point of view, Energy Conversion and Management, Vol.67, pp.66-74.

[12] Hadidi, A., Nazari, A. 2013. Design and economic optimization of shell and tube heat exchangers using biogeography-based (BBO) algorithm, Applied Thermal Engineering, Vol.51, pp.1263-1272.

[13] Khosravi, R., Khosravi, A., Nahavandi, S., Hajabdollahi $H$,
2015. Effectiveness of evolutionary algorithms for optimization of heat exchangers, Energy Conversion and Management, Vol. 89, pp.281-288.

[14] Selbaş, R., Kızılkan, O., Reppich, M. 2006. A new design approach for shell and tube heat exchangers using genetic algorithms from economic point of view, Chemical Engineering and Processing, Vol.45, pp. $268-275$.

[15] Şahin, A.S., Kılıc, B., Kılıc, U. 2011. Design and economic optimization of shell and tube heat exchangers using Artificial Bee Colony (ABC) algorithm, Energy Conversion and Management, Vol.52, pp.3356 3362.

[16] Sadeghzadeh, H., Ehyaei, M.A., Rosen, M.A. $2015 . \quad$ Technoeconomic optimization of a shell and tube heat exchanger by genetic and particle swarm algorithms, Energy Conversion and Management, Vol. 93, pp.84-91.

[17] Sanaye, S., Hajabdollahi, H. 2010. Multi objective optimization of shell and tube heat exchangers, Applied Thermal Engineering, Vol.30, pp.1937 - 1945.

[18] Patel, V.K., Rao, R.V. 2010. Design optimization of shell and tube heat exchanger using particle swarm, Applied Thermal Engineering, Vol.30, pp.1417 - 1425.

[19] Sun, S., Lu, Y., Yan, C. 1993. Optimization in calculation of shell and tube heat exchanger, International Communication in Heat and Mass Transfer,Vol.20, pp.675 - 685 .

[20] Ozcelik, Y. 2007. Exergetic optimization of shell and tube heat exchangers using genetic based algorithm, Applied Thermal Engineering, Vol. 27, pp.1846 1856. 
O.E. Turgut, Multi-Objective Thermal Design of a Shell and Tube Condenser through Global Best Algorithm

[21] Hajabdollahi, H., Ahmadi, P., Dincer I. 2012. Exergetic optimization of shell and tube heat exchnagers using NSGA - II, Heat Transfer Engineering, Vol.33, pp.618-628.

[22] Haseli, Y., Dincer, I., Natarer, G.F. 2010. Exergy efficiency of two phase flow in a shell and tube condenser, Heat Transfer Engineering, Vol.31, pp.17 - 24 .

[23] Kovarik, M. 1989. Optimal heat exchnagers, Journal of Heat Transfer, Vol.111, pp.1846 - 1856.

[24] Fax, D.H., Mills, R.R. 1957. Generalized optimal heat exchanger design, ASME Transactions, Vol.79, pp.653 - 661 .

[25] Unuvar, A., Kargici, S. 2004. An approach for optimum design of heat exchanegrs, An approach for optimum design of heat exchangers, International Journal of Energy Research, Vol. 28, pp.1379 $-1392$.

[26] Afimiwala, K.A. 1976. Interactive computer methods for design optimization, Ph.D. Thesis, Mechanical Engineering Department, State University of New York at Buffola

[27] Paul, H. 1982. An application of geometric programming to heat exchanger design, Computers and Industrial Engineering, Vol.6, pp.103 - 114 .

[28] Radhakrishnan, V.R., Gupta, B.R., Jairaman, V. 1980. Optimum design of shell and tube heat exchangers by geometric programming, Indian Journal of Technology, Vol.18, pp.293 - 300.

[29] Babu, B.V., Mohiddin, S.B. 1999. Automated design of heat exchangers using artificial intelligence based optimization, In: Proceedings of International Symposium and 52 ${ }^{\text {nd }}$ Annual Session of IIChE (CHEMCON - 99), Punjab University, Chandigarh, December $20-23$.

[30] Tayal, M.C., Fu, Y., Diwekar, U.M. 1999. Optimal design of heat exchangers: a genetic algorithm framework, Industrial Engineering Chemical Research, Vol.38, pp.456 $-467$.

[31] Babu, B.V., Munawar, S.A. 2007. Differential evolution strategies for optimal design of shell and tube heat exchangers, Chemical Engineering Science, Vol.62, pp.3720 - 3739.

[32] Hajabdollahi, H., Ahmadi, P., Dincer, I. 2011. Thermoeconomic optimization of shell and tube condenser using both genetic and particle swarm, International Journal of Refrigeration, Vol.34, pp.1066 - 1076.

[33] Chaudhuri, P.D., Urmila, M.D., Jefery, S.L. 1997. An automated approach for the optimal design of heat exchangers, Industrial \& Engineering Chemistry Research, Vol.36, pp.3685-3693.

[34] Haseli, Y., Dincer, I., Natarer, G.F. 2008. Optimum temperatures in a shell and tube condenser with respect to exergy, International Journal of Heat and Mass Transfer, Vol.51, pp.2462 - 2470.

[35] Khalifeh Soltan, B., Saffar-Avval, M., Damangir, E. 2004. Minimizing capital and operating costs of shell and tube condensers using optimum baffle spacing, Applied Thermal Engineering, Vol. 24, pp.2801 - 2810.

[36] Taal, M., Bulatov, I., Klemes, J., Stehlik, P. 2003. Cost estimation and energy price forecasts for economic evaluation of retrofit projects, Applied Thermal Energy, Vol.23, pp.1819-1835. 
O.E. Turgut, Multi-Objective Thermal Design of a Shell and Tube Condenser through Global Best Algorithm

[37] Civicioglu, P. 2013. Backtracking Search Optimization Algorithm for numerical optimization problems, Applied Mathematics and Computation, Vol. 219, pp. 8121 8144.

[38] Yadav, P., Kumar, R., Panda, S.K., Chang, C.S., 2012. An Intelligent Tuned Harmony Search algorithm for optimisation, Information Sciences, Vol.196, pp.47-72.

[39] Yang, X.S. 2010. A New Metaheuristic Bat-Inspired Algorithm, In: Nature Inspired Cooperative Strategies for Optimization (NISCO 2010)" Studies In Computatonal Intelligence, Vol. 284, pp.65 - 74

[40] Sun, J., Feng, B., Xu, W.B. 2004. Particle swarm optimization with particles having quantum behavior, IEEE Proceedings of Congress on Evolutionary Computation, pp.325 $-331$.

[41] Erol, 0.K., Eksin, I. 2006. A new optimization method:Big Bang-Big Crunch, Advances in Engineering Software, Vol. 37, pp.106-111.

[42] Civicioglu, P., 2012. Transforming geocentric cartesian coordinates to geodetic corrdinates by using differential search algorithm, Computers \& Geosciences, Vol.46, pp.229- 247.

[43] Kennedy, J., Eberhart, R. 1995. Particle Swarm Optimization, In:Proceeedings of IEEE International Conference on Neural Networks.IV, pp. 1942 - 1948.

[44] Storn, R., Price, K. 1997. Differential evolution - a simple and efficient heuristic for global optimization over continuous spaces, Journal of Global Optimization, Vol. 11, pp. 341 - 359.

[45] Turgut, O.E., Coban, M.T. 2017. Thermal design of spiral heat exchangers and heat pipes through global best algorithm, Heat and Mass Transfer, Vol. 53, pp.899-916

[46] Arora, R., Kaushik, S.C., Kumar, R., Arora, R. 2016. Soft computing based multi-objective optimization of Brayton cycle power plant with isothermal heat addition using evolutionary algorithm and decision making, Applied Soft Computing, Vol.46, pp.267-283. 